\title{
Study of Structural and Optoelectronic Properties of ZnO Codoped with $\mathrm{Ca}$ and $\mathrm{Mg}$
}

\author{
Manoj Kumar Mishra, ${ }^{1}$ Amarendra Narayan, ${ }^{1}$ Rakesh Kumar Singh, \\ Raghvendra Singh Yadav, ${ }^{3}$ Navendra Kumar Nidhi, ${ }^{4}$ and Avinash Chandra Pandey ${ }^{5}$ \\ ${ }^{1}$ P. G. Department of Physics, Patna Science College, Patna University, Patna-800005, Bihar, India \\ ${ }^{2}$ Aryabhatta Centre for Nanoscience and Nanotechnology, Aryabhatta Knowledge University, Patna, Bihar, India \\ ${ }^{3}$ Material Research Centre, Brno University of Technology, Brno, Czech Republic \\ ${ }^{4}$ Physics Department, R. R. M. Campus, Janakpur District, Dhanusha, Nepal \\ ${ }^{5}$ Nanotechnology Application Centre, Allahabad University, Allahabad, Uttar Pradesh, India
}

Correspondence should be addressed to Manoj Kumar Mishra; manoj.phyl@gmail.com

Received 1 August 2013; Accepted 1 September 2013

Academic Editors: M. Jayachandran and K. Kalantar-Zadeh

Copyright (c) 2013 Manoj Kumar Mishra et al. This is an open access article distributed under the Creative Commons Attribution License, which permits unrestricted use, distribution, and reproduction in any medium, provided the original work is properly cited.

$\mathrm{ZnO}$ codoped with $\mathrm{Ca}$ and $\mathrm{Mg}$ in various proportions was prepared by a chemical method and annealed at $600 \mathrm{C}$. The structural and optical properties of these oxide samples were systematically studied by XRD, SEM, EDS, and PL spectrometer. XRD pattern shows a hexagonal wurtzite structure. The size of particle as shown by XRD machine and calculated by Scherer's formula is found in the nano range. The formation of particles showed that they were polycrystalline. Due to larger ionic and covalent radii of Ca than those of Zinc, a lattice deformation occurs with the development of strain field. New phases were observed in XRD pattern of few samples $\mathrm{ZnO}-2.2$ and $\mathrm{ZnO}-2.4$. SEM micrograph shows the formation of nanoparticles. EDS study confirms the codoping of $\mathrm{ZnO}$ with $\mathrm{Ca}$ and $\mathrm{Mg}$. Optical properties like photoluminescence emission showed a blue shift in peak wavelength. General conductivity and photoconductivity were found high in samples containing certain proportion of $\mathrm{Ca}$ and $\mathrm{Mg}$ in comparison with pure $\mathrm{ZnO}$.

\section{Introduction}

Zinc Oxide has attracted a lot of research interest due to its enormous potential for application in a variety of optoelectronic and electronic devices. The main advantages of $\mathrm{ZnO}$ for optoelectronic applications are its large exciton binding energy [ $60 \mathrm{mev}]$, wide band gap energy of $3.2 \mathrm{ev}$ at room temperature, and the existence of well developed bulk and epitaxial growth processes. $\mathrm{ZnO}$ can be prepared by an easy and cheap chemical method. It is nonpoisonous; so it can be used widely. $\mathrm{ZnO}$ thin films are used as transparent electrodes in photovoltaic cell in place of expensive Indium Tin Oxide [1]. $\mathrm{ZnO}$ nanowires have also been investigated as gas sensors [2,3]. $\mathrm{ZnO}$ is suitable for UV detection by using its photoconduction properties [3]. $\mathrm{ZnO}$ normally forms in the hexagonal (wurtzite) crystal structure with $a=3.25 \mathrm{~A}$ and $c=5.12 \mathrm{~A}$. The $\mathrm{Zn}$ atoms are tetrahedrally coordinated with four $\mathrm{O}$ atoms where the d-electrons of $\mathrm{Zn}$ hybridize with the p-electrons of O. Layers occupied by Zinc atoms alternate with layers occupied by Oxygen atoms. Presence of free electrons in undoped $\mathrm{ZnO}$ has been attributed to $\mathrm{Zn}$ interstitials and Oxygen vacancies [4]. The intrinsic defect levels that lead to $\mathrm{n}$-type doping lie approximately 0.01 to $0.05 \mathrm{ev}$ below the conduction band. The photoluminescence study of $\mathrm{ZnO}$ reflect the intrinsic direct band gap, a strongly bound exciton state, and the gap states due to point defects [4]. Visible emissions in violet blue, green, and red orange range in case of $\mathrm{ZnO}$ are due to transitions between selfactivated centers formed by doubly ionized Zinc Vacancy and an ionized interstitial $\mathrm{Zn}+$, Oxygen vacancies, and donor acceptor pair recombination involving an impurity acceptor [4].

For the fabrication of optoelectronic devices, knowledge about the properties of impurities like donors and acceptors is 


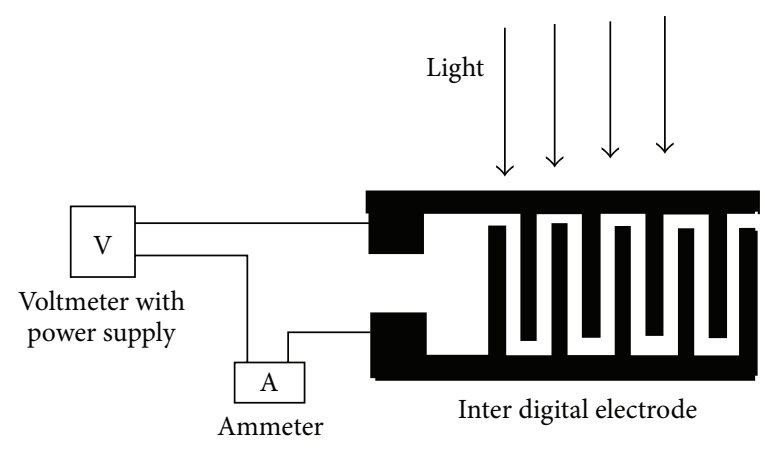

FIgURE 1: Circuit for photoconductivity measurement.

of essential interest. The binding mechanism can be described as a consequence of the lattice deformation due to atomic size difference between impurity and host atom. The replacement of host atom on cation site has been reported in many journals. Preparation and characterization of alloys like (Zn$\mathrm{Ca}-\mathrm{Mg}$ ) $\mathrm{O}$ are important for band gap engineering, as $\mathrm{p}$ $n$ junction applications and creating a new combinations to form a substance of modified optical properties. Covalent radii of $\mathrm{Zn}, \mathrm{Ca}$, and $\mathrm{Mg}$ are 122,176 , and $141 \mathrm{pm}$, respectively. Similarly, ionic radii of $\mathrm{Zn}, \mathrm{Ca}$, and $\mathrm{Mg}$ are 88,114 and 86 pm, respectively [4]. Ca having larger radii, can set in place of $\mathrm{Zn}$ in $\mathrm{ZnO}$ lattice structure with less deformation. Few work have been done on doping $\mathrm{ZnO}$ with other elements, but work on codoping $\mathrm{ZnO}$ with $\mathrm{Ca}$ and $\mathrm{Mg}$ has not been done. Our effort is to find certain proportion of dopant like $\mathrm{Ca}$ and $\mathrm{Mg}$ in $\mathrm{ZnO}$ which will increase the conductive behavior. We have prepared the samples by a simple and economical chemical method. Samples were characterized by XRD and PL spectrometer. General and photoconductivity studies were done on $\mathrm{Ca}-\mathrm{Mg}$ codoped $\mathrm{ZnO}$ nanocrystals.

\section{Experimental}

The chemical route is simple and economical for preparing high quality nanomaterial like Zinc Oxide. Zinc Oxide nanoparticle can be prepared by treating Zinc Sulphate or Zinc Nitrate with Sodium Hydroxide in aqueous solution and then heating the white precipitate (Zinc Hydroxide) at a temperature greater than $100 \mathrm{C}$. All chemicals used were of high purity taken from Merc India Ltd. To prepare pure Zinc Oxide, nanomaterial Zinc Nitrate and Sodium Hydroxide were taken in stoichiometric ratio in aqueous solution and stirred for 12 hours. The white precipitate was washed with deionized water 8 times so that only Zinc Hydroxide precipitate remained. It was then dried at $100^{\circ} \mathrm{C}$ for 2 hours. Dried samples were annealed at $600 \mathrm{C}$ for half an hour. Next for doping with $\mathrm{Ca}$ and $\mathrm{Mg}$, their nitrates were mixed with Zinc Nitrate in the ratio such that the number of atoms of $\mathrm{Zn}$ and those of ( $\mathrm{Ca}$ and $\mathrm{Mg}$ ) were in the ratio of $90: 10$. The amount of $\mathrm{Ca}$ and $\mathrm{Mg}$ were varied to obtain samples containing the number of atoms of $\mathrm{Ca}$ and $\mathrm{Mg}$ in $(0,10),(2,8),(4,6),(6,4),(8,2)$, and $(10,0)$ percent ratios. The percentage of $\mathrm{Ca}$ and $\mathrm{Mg}$ can be expressed by equation as $\mathrm{Zn}_{0.9} \mathrm{Ca}_{x} \mathrm{Mg}_{0.1-x} \mathrm{O}$, where $x=0,0.02,0.04,0.06,0.08$, and 0.1. Each sample was dried and then annealed at $600 \mathrm{C}$. The XRD patterns of these samples were obtained by Rigaku Miniflex 2 X-ray Diffractometer with $\mathrm{Cu} \mathrm{K} \alpha$ X-radiation of wavelength 1.5406 Ångstrom. Photoluminescence spectra of all samples were studied with excitation wavelengths of $254 \mathrm{~nm}$ by the help of Fluorescence spectrometer (Perkin Elmer LS 55). The photoconduction studies were done by pressing $\mathrm{ZnO}$ nanopowders on self-designed interdigital electrode and covering it with glass cavity and illuminating it with visible light from general $100 \mathrm{~W}$ bulb kept at two heights such that the illuminance at the sample is $40 \mathrm{Lx}, 332 \mathrm{Lx}$, and 1640 Lx, respectively (Figure 1). The effective area of crosssection (A) and effective length between two electrodes (L) for the calculation of resistivity were taken as $(2.4 \times 0.15 \times 7+$ $3.6 \times 0.5=4.32 \mathrm{~cm}^{2}$ ) and $0.15 \mathrm{~cm}$, respectively, by measuring the dimension of electrode.

\section{Results and Discussions}

The $\mathrm{ZnO}$ samples containing different proportions of $\mathrm{Ca}$ and $\mathrm{Mg}$ are coded as given below.

$\mathrm{Zn}_{0.9} \mathrm{Ca}_{0} \mathrm{Mg}_{0.1} \mathrm{O}$ :- $\mathrm{ZnO}-2.1, \mathrm{Zn}_{0.9} \mathrm{Ca}_{0.02} \mathrm{Mg}_{0.08} \mathrm{O}$ :- $\mathrm{ZnO}-$ 2.2, $\mathrm{Zn}_{0.9} \mathrm{Ca}_{0.04} \mathrm{Mg}_{0.06} \mathrm{O}$ :- $\mathrm{ZnO}-2.3, \mathrm{Zn}_{0.9} \mathrm{Ca}_{0.06} \mathrm{Mg}_{0.04} \mathrm{O}$ :$\mathrm{ZnO}-2.4, \mathrm{Zn}_{0.9} \mathrm{Ca}_{0.08} \mathrm{Mg}_{0.02} \mathrm{O}$ :- $\mathrm{ZnO}-2.5, \mathrm{Zn}_{0.9} \mathrm{Ca}_{0.1} \mathrm{Mg}_{0} \mathrm{O}$ :$\mathrm{ZnO}-2.6$.

XRD patterns of Pure Zinc Oxide showed that the formation was polycrystalline. The doping of $\mathrm{ZnO}$ with $\mathrm{Ca}$ and $\mathrm{Mg}$ such that the number of doped atoms is up to $10 \%$ of the number of $\mathrm{Zn}$ atoms form the new substance. They have the same phases as that of $\mathrm{ZnO}$ except the formation of few new phases in samples number $\mathrm{ZnO}-2.2$ and $\mathrm{ZnO}$ 2.4. The size of nanoparticle was in the range of $20 \mathrm{~nm}$ to $50 \mathrm{~nm}$. The peaks were found in basically 8 directions (100, $002,101,102,110,103,112$, and 201) among which prominent peak was in the third, that is, (101), direction. The distance between two planes of crystal and the size of nanoparticles was calculated by Rigaku software and by Scherrer equation, $\{D=0.9 \lambda / \beta \cos \theta\}$ where $D$ is the size of crystal, $\lambda$ is the wavelength of X-ray 1.5406 Angstrom, $\beta$ is the full width at half of maximum(FWHM), and $\theta$ is the angle of diffraction. The XRD pattern of all samples $\mathrm{ZnO}$ pure, $\mathrm{ZnO}-2.1, \mathrm{ZnO}-2.2$, $\mathrm{ZnO}-2.3, \mathrm{ZnO}-2.4, \mathrm{ZnO}-2.5$ and $\mathrm{ZnO}-2.6$ as found is shown in order in Figure 2. 


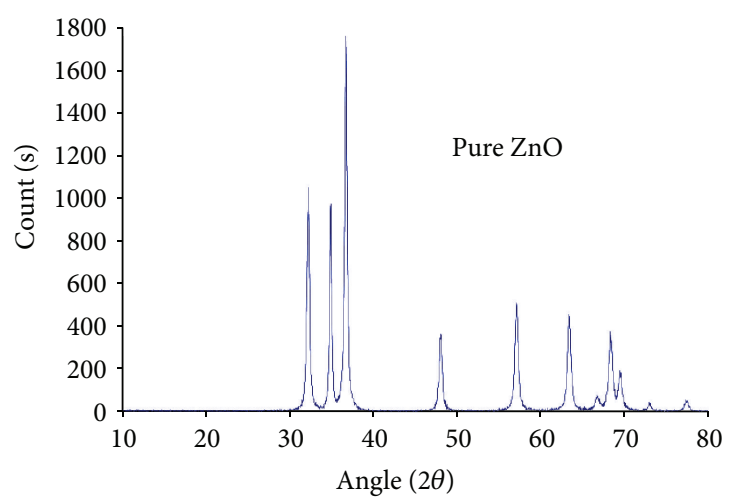

(a)

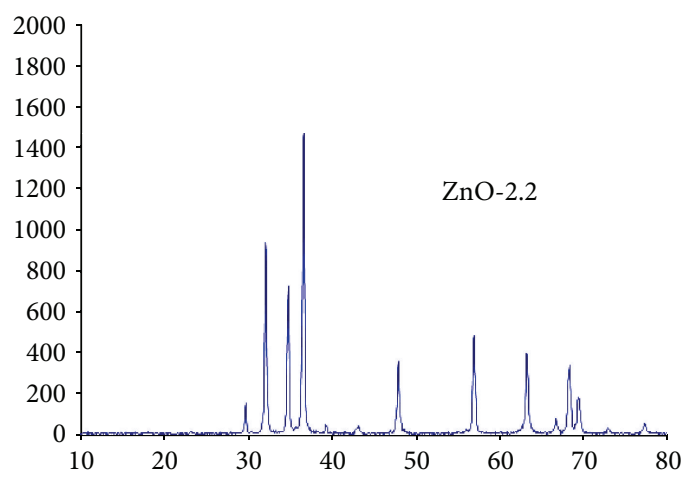

(c)

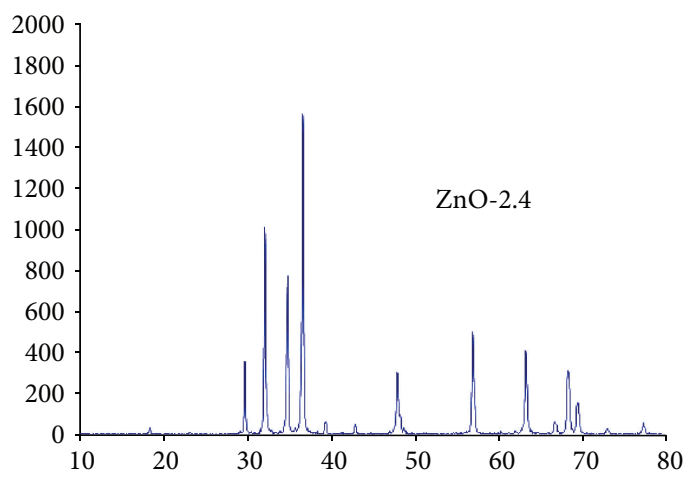

(e)

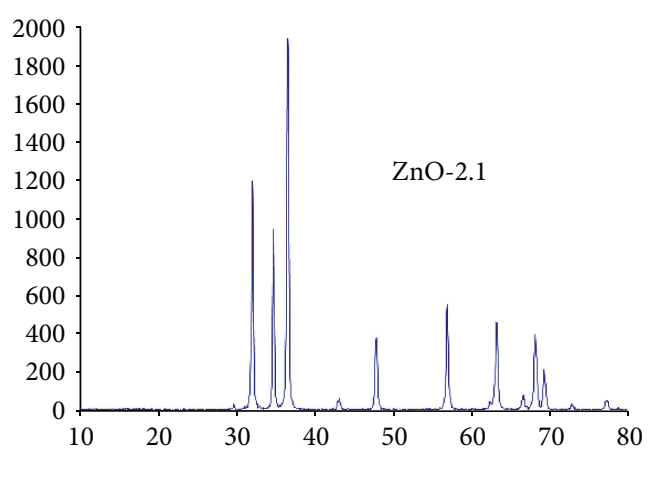

(b)

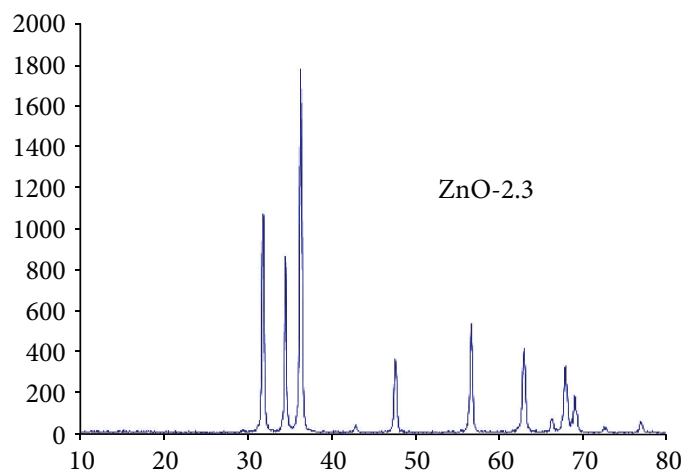

(d)

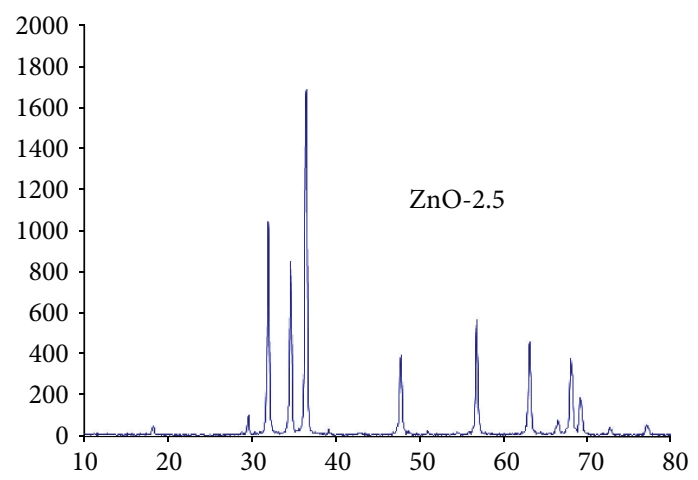

(f)

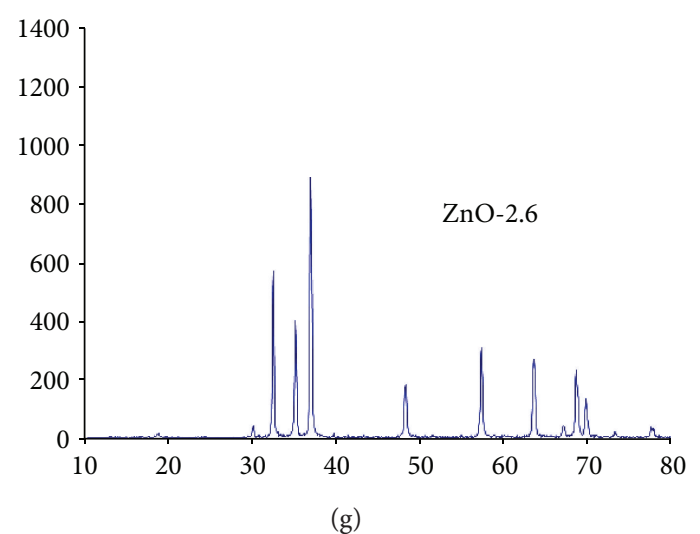

FIGURE 2 


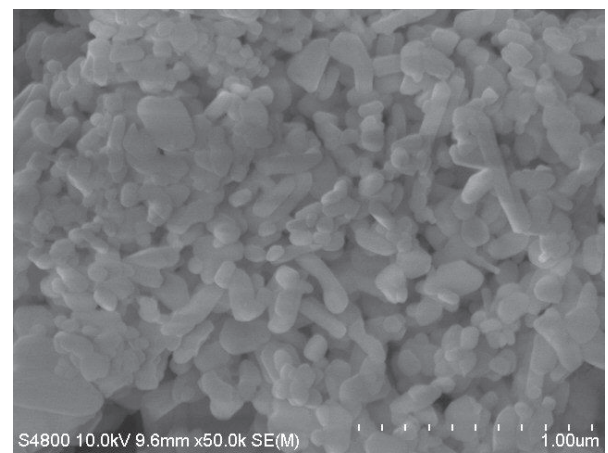

(a)

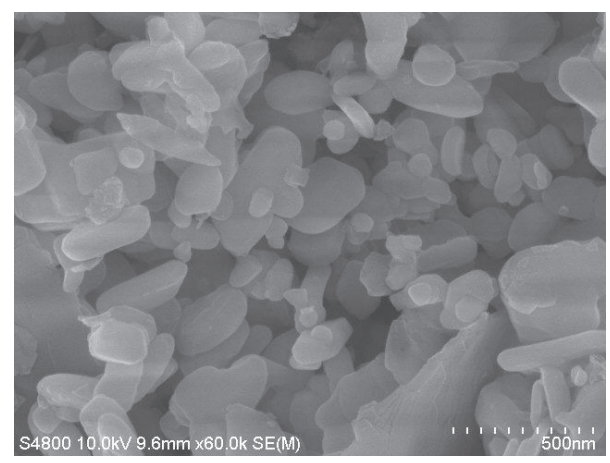

(b)

Figure 3: SEM micrograph of $\mathrm{Zn}_{0.9} \mathrm{Ca}_{0} \mathrm{Mg}_{0.1} \mathrm{O}(\mathrm{ZnO}-2.1)$.

TABLE 1

\begin{tabular}{lccc}
\hline $\mathrm{Zn}_{0.9} \mathrm{Ca}_{0} \mathrm{Mg}_{0.1} \mathrm{O}$ & $\mathrm{O}$ & $\mathrm{Zn}$ & $\mathrm{Mg}$ \\
\hline Atomic percentage & $59.49 \%$ & $36.42 \%$ & $4.09 \%$ \\
\hline
\end{tabular}

SEM micrograph shows that $\mathrm{ZnO}$ powder was with small grain of size in nanorange. The SEM study of samples was done one year after its preparation so the size of grain was increased comparing to that found by XRD machine which was smaller than $50 \mathrm{~nm}$ at the time of preparation. The structure of grain was like long stones. The picture is given in Figure 3.

The atomic percentage of all elements as studied by the help of EDS of $\mathrm{Zn}_{0.9} \mathrm{Ca}_{0} \mathrm{Mg}_{0.1} \mathrm{O}$ [ZnO-2.1] is as shown in Table 1.

EDS study confirm the presence of $\mathrm{Mg}$ in $\mathrm{ZnO}$. The amount of $\mathrm{Ca}$ is zero matching with the intended doping amount. The amount of doped elements $\mathrm{Ca}$ and $\mathrm{Mg}$ is found to be less than the actual amount intended to dope in $\mathrm{ZnO}$. This may be due to inhomogeneity of sample.

The spectrum obtained by EDS study of $\mathrm{Zn}_{0.9} \mathrm{Ca}_{0} \mathrm{Mg}_{0.1} \mathrm{O}$ [ $\mathrm{ZnO}-2.1]$ is given in Figure 4.

PL measurement of doped Zinc Oxide was done at excitation wavelength $254 \mathrm{~nm}$. Figure 5 represents the PL spectra of doped Zinc Oxide at excitation wavelength of $254 \mathrm{~nm}$ at room temperature. There are five sharp peaks in case of pure $\mathrm{ZnO}$ and three peaks in case of doped samples at room temperature. The exciton emission (in UV range)

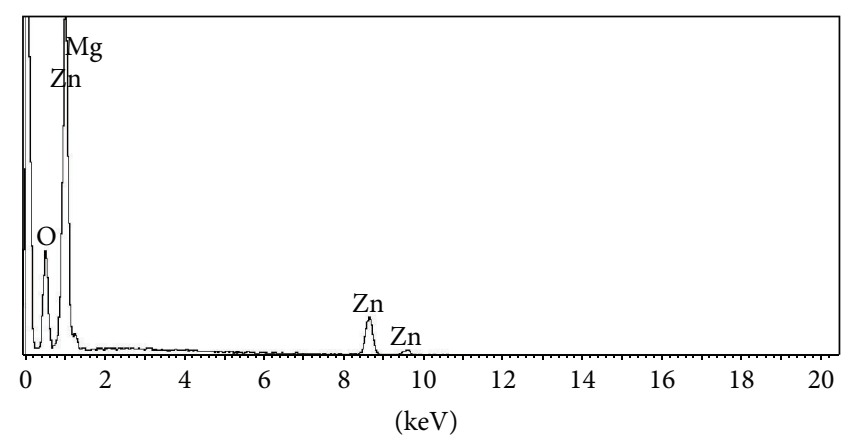

Full scale 2610 cts cursor: 0.000

Figure 4: EDS study of $\mathrm{ZnCaMgO}$ ( $\mathrm{ZnO}-2.1)$.

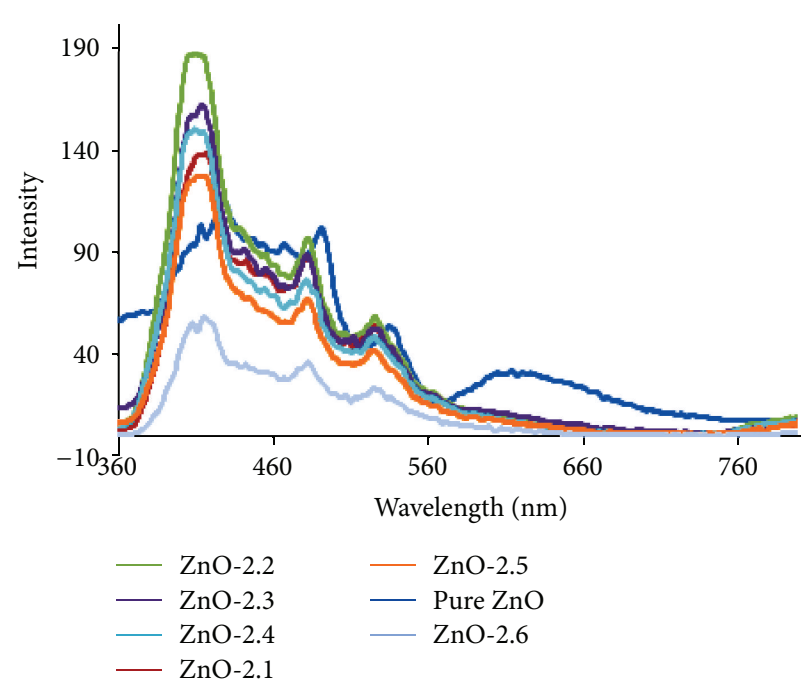

Figure 5: Photoluminescence spectra of $\mathrm{ZnCaMgO}$ ( $\mathrm{ZnO}-2$ series).

is found in case of pure and doped $\mathrm{ZnO}$ but peaks are not found. The first peak in case of Pure $\mathrm{ZnO}$ is at $414 \mathrm{~nm}$ while in case of doped are from 410-417 $\mathrm{nm}$ (violet range). The second peak in case of pure $\mathrm{ZnO}$ is at $429 \mathrm{~nm}$ while in doped $\mathrm{ZnO}$ is absent. Third peaks are in $482-483 \mathrm{~nm}$ (blue range) while for pure $\mathrm{ZnO}$ is $491.5 \mathrm{~nm}$, fourth peaks are in 525-527 nm (green range) while for pure $\mathrm{ZnO}$ is $534.5 \mathrm{~nm}$. Third and fourth peaks are little blue shifted due to more electrons contributed by the dopant. Fifth peak is only in case of pure $\mathrm{ZnO}$ at 616$620 \mathrm{~nm}$ (red range). The radiation in visible range is due to recombination between point defects and oxygen vacancies. The intensities of peak are not in certain order because the number of defects depend on the amount of oxygen present in the atmosphere during annealing of samples.

The study of photoconduction reveal that pure and doped $\mathrm{ZnO}$ are photosensitive. The amount of current increases as the light intensity falling on the sample surface is increased. The sample illuminated with light intensities $40 \mathrm{Lx}, 332 \mathrm{Lx}$, and $1640 \mathrm{Lx}$ are coded as $\mathrm{A}, \mathrm{B}$, and $\mathrm{C}$, respectively. The amount of current is very low in case of pure $\mathrm{ZnO}$, that is, less than $0.6 \mu \mathrm{A}$. The amount of current is enormously high 


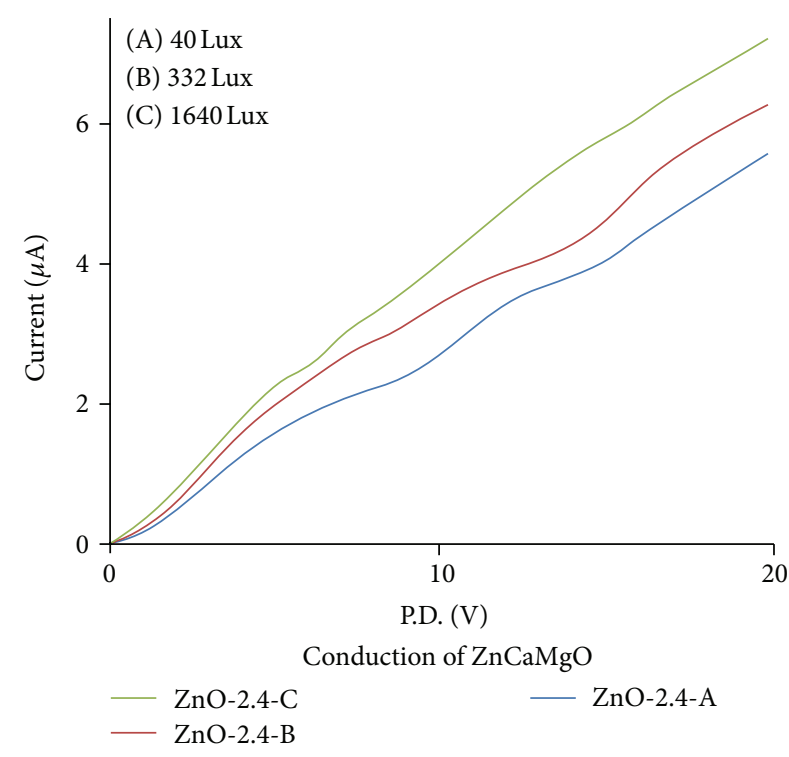

(a)

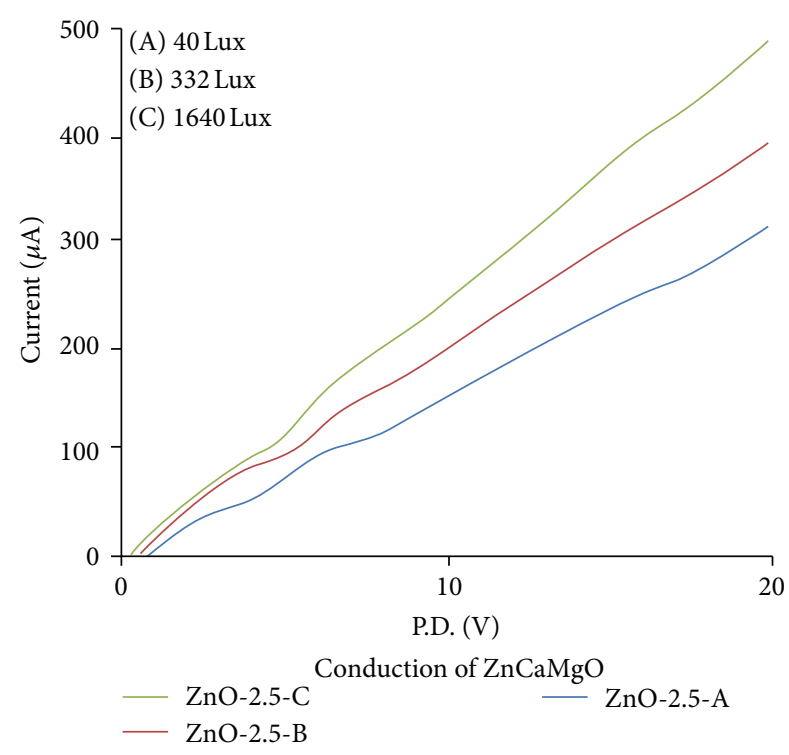

(b)

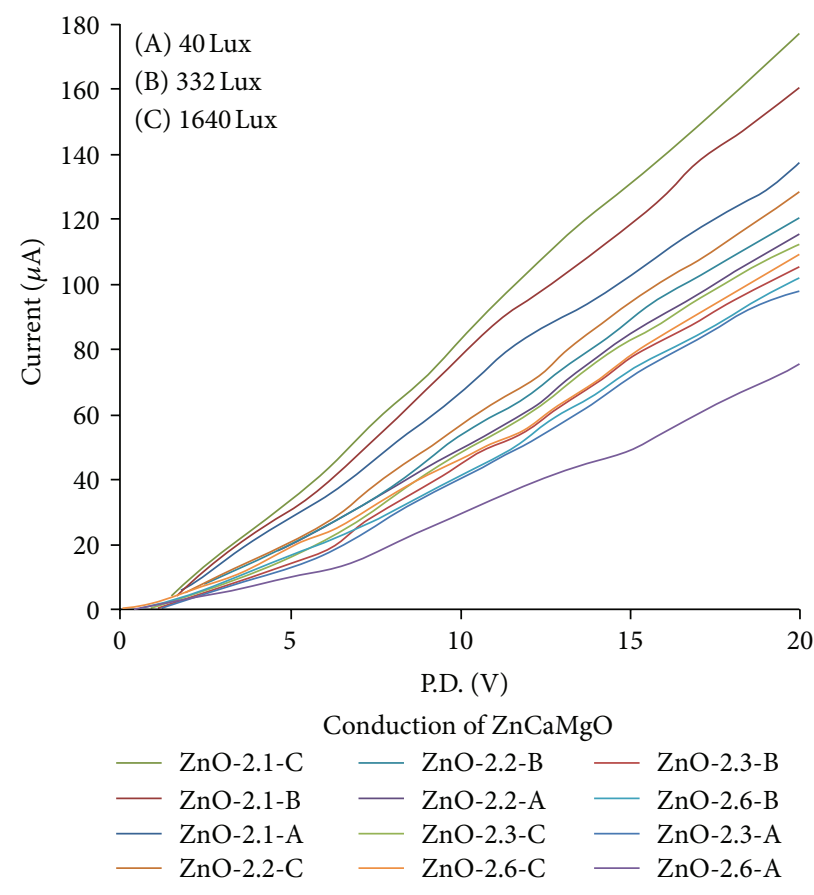

(c)

Figure 6

in case of the sample $\mathrm{ZnO}-2.5$ in which amount of $\mathrm{Ca}$ and $\mathrm{Mg}$ is in ratio $(80: 20)$. The observed resistance and resistivity of all samples are given in Table 2. The least resistivity of doped $\mathrm{ZnO}$ [i.e., $\mathrm{Zn}_{0.9} \mathrm{Ca}_{0.08} \mathrm{Mg}_{0.02} \mathrm{O}$ ] was found to be $1.81131840 \Omega$ $\mathrm{Cm}$ which is very small in comparison with that of undoped $\mathrm{ZnO}$ [i.e., $976.27118 \Omega-\mathrm{Cm}$ ]. The least resistivity is still higher than that of doped $\mathrm{ZnO}$ found by other researchers. This is due to the less compactness of powder in comparison to that of film. The current (in $\mu \mathrm{A}$ ) verses potential difference (in $\mathrm{V}$ ) graph at different light intensities are shown in Figure 6.
The data of particle size, interplanar distance, average resistance, resistivity, and initial rate of decay of current can be tabulated as shown in Table 2 .

\section{Conclusion}

$\mathrm{ZnO}$ was doped successfully by a very simple chemical method. XRD pattern shows its high crystallinity. New phases were found in few samples, $\mathrm{ZnO}-2.2$ and $\mathrm{ZnO}-2.4$. The SEM 
TABLE 2

\begin{tabular}{lccccc}
\hline Sample name & $\begin{array}{c}\text { Particle size in } \\
{[101] \text { direction }} \\
\text { in }(\mathrm{nm})\end{array}$ & $\begin{array}{c}\text { Interplanar } \\
\text { distance }[d] \text { in } \\
\text { Angstrom }\end{array}$ & $\begin{array}{c}\text { Average } \\
\text { resistance } \\
(\Delta V / \Delta I) \text { in } \mathrm{M} \Omega\end{array}$ & $\begin{array}{c}\text { Resistivity } \\
(\rho=R A / L) \\
\text { in } \Omega \text {-Cm }\end{array}$ & $\begin{array}{c}\text { Intial rate of } \\
\text { decay of current } \\
\text { in } \mu \mathrm{A} / \mathrm{S}\end{array}$ \\
\hline Pure ZnO & 26 & 2.4590 & 33.333333 & 976.27118 \\
$\mathrm{ZnO}-2.1$ & 37.7 & 2.4650 & 0.1438848 & 4.14388224 & 0 \\
$\mathrm{ZnO}-2.2$ & 35 & 2.4544 & 0.1724137 & 4.96551456 & 0 \\
$\mathrm{ZnO}-2.3$ & 33.8 & 2.4746 & 0.2020202 & 5.81818176 & 0 \\
$\mathrm{ZnO}-2.4$ & 44.9 & 2.4543 & 3.5087719 & 101.052631 & 0 \\
$\mathrm{ZnO}-2.5$ & 37.6 & 2.4654 & 0.0628930 & 1.81131840 & 0 \\
$\mathrm{ZnO}-2.6$ & 40.3 & 2.4279 & 0.2631578 & 7.57894464 & 0 \\
\hline
\end{tabular}

micrograph shows the formation of nanoparticles of $\mathrm{ZnO}$. EDS study shows the success of doping $\mathrm{ZnO}$ with $\mathrm{Mg}$. The presence of $\mathrm{Ca}$ was not seen due to the test of first sample [ZnO-2.1] in which amount of Ca was intentionally doped zero percent. PL study shows a little blue shift in the blue and green range emission due to doping with $\mathrm{Ca}$ and $\mathrm{Mg}$. Photoconductive study reveal that when the amount of $\mathrm{Ca}$ increases and that of $\mathrm{Mg}$ decreases, the resistance increase, that is, conductance decrease up to certain proportion of $\mathrm{Ca}$ and $\mathrm{Mg}$ [Ca-6\%, Mg-4\%] in $\mathrm{ZnO}$ for which it is highly conductive in comparison with pure $\mathrm{ZnO}$. It shows that the presence of both elements $\mathrm{Ca}$ and $\mathrm{Mg}$ in $\mathrm{ZnO}$ increases its conductivity.

\section{References}

[1] Ü. Özgür, Y. I. Alivov, C. Liu et al., "A comprehensive review of ZnO materials and devices," Journal of Applied Physics, vol. 98, no. 4, Article ID 041301, 103 pages, 2005.

[2] Z. L. Wang, "Zinc oxide nanostructures: growth, properties and applications," Journal of Physics Condensed Matter, vol. 16, no. 25, pp. R829-R858, 2004.

[3] P. Sharma, K. Sreenivas, and K. V. Rao, "Analysis of ultraviolet photoconductivity in $\mathrm{ZnO}$ films prepared by unbalanced magnetron sputtering," Journal of Applied Physics, vol. 93, no. 7, pp. 3963-3970, 2003.

[4] D. Banerjee, J. Y. Lao, D. Z. Wang et al., "Synthesis and photoluminescence studies on $\mathrm{ZnO}$ nanowires," Nanotechnology, vol. 15, no. 3, pp. 404-409, 2004. 

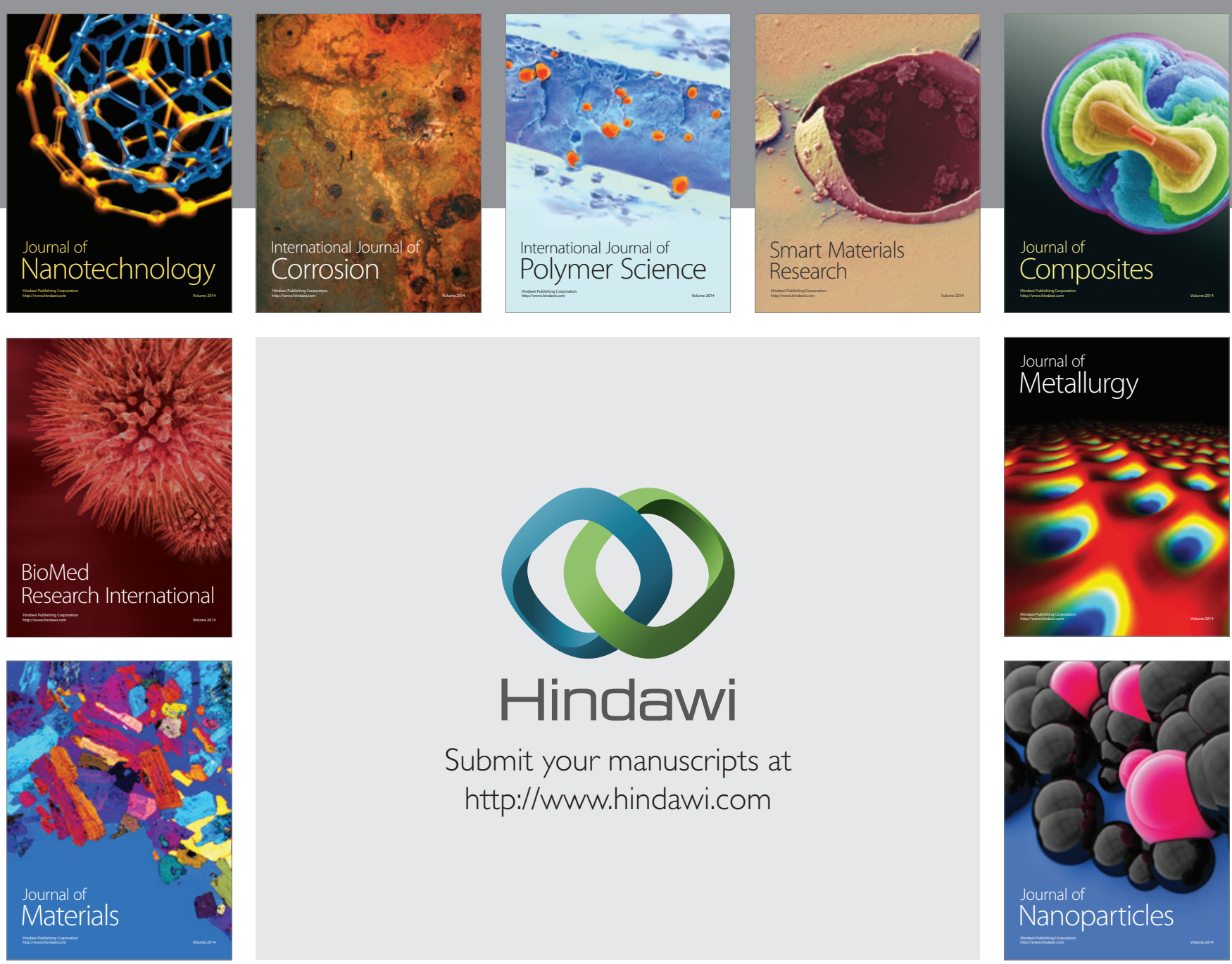

Submit your manuscripts at http://www.hindawi.com
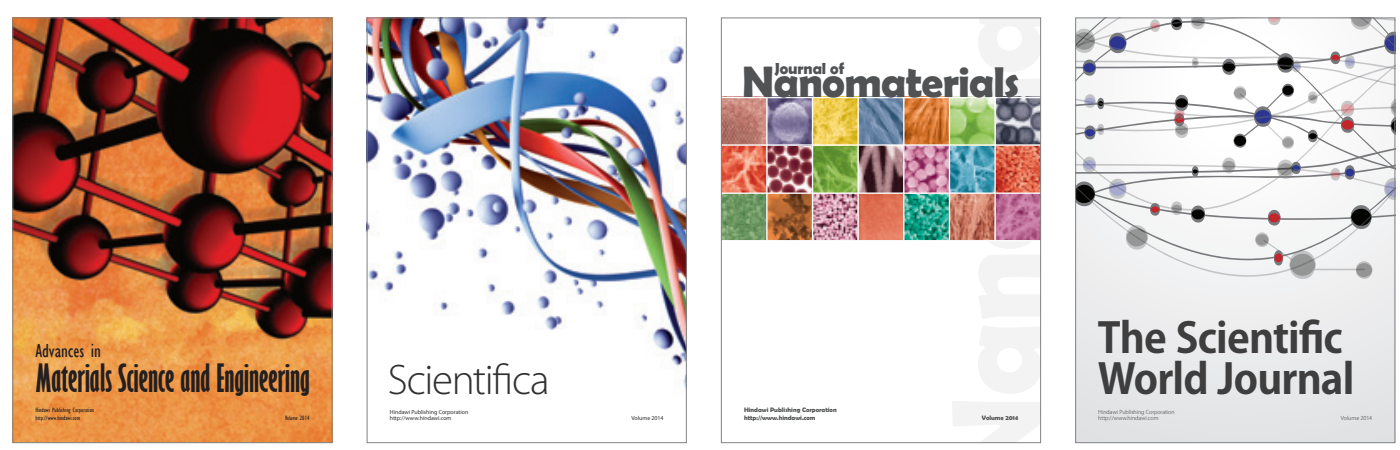

\section{The Scientific World Journal}
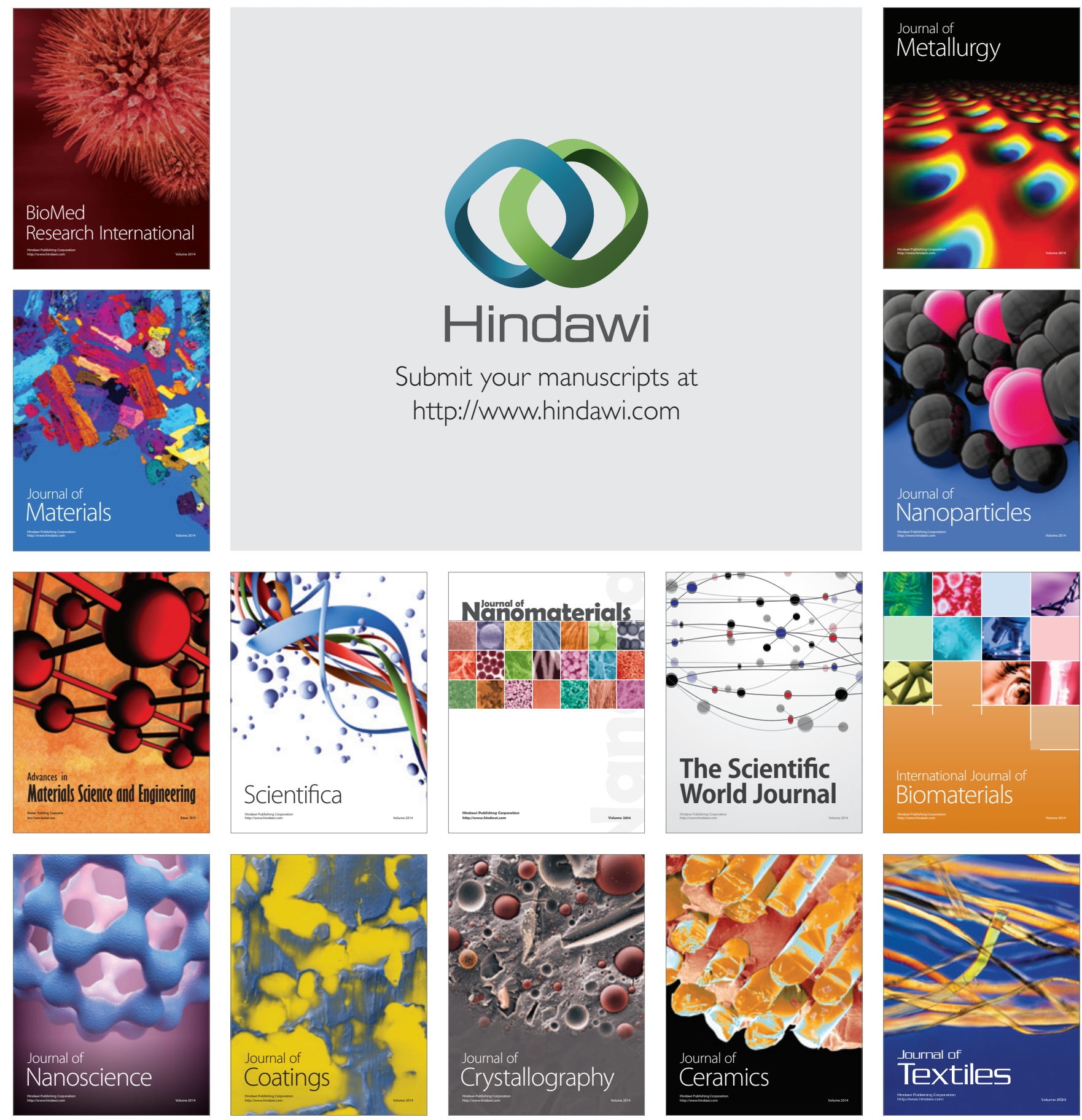